\title{
Liver safety assessment in clinical trials of new agents for chronic hepatitis B
}

\author{
Robert J. Fontana ${ }^{1}$ | Mark I. Avigan ${ }^{2}$ | Harry L. A. Janssen ${ }^{3}$ | Arie Regev ${ }^{4}$ | \\ Poonam Mishra $^{5}$ | Anuj Gaggar ${ }^{6}$ | Nathaniel Brown ${ }^{7}$ | Cynthia Wat ${ }^{8}$ | \\ Patricia Mendez $^{9}$ | Ryan T. Anderson ${ }^{10}$ | Bruce Given ${ }^{11}$ | Veronica Miller ${ }^{10}$ (iD \\ Maria Beumont ${ }^{12}$ \\ ${ }^{1}$ Division of Gastroenterology and Hepatology, University of Michigan, Ann Arbor, MI, USA \\ ${ }^{2}$ Office of Surveillance and Epidemiology, Center for Drug Evaluation and Research, US Food and Drug Administration, Silver Spring, MD, USA \\ ${ }^{3}$ Toronto Centre for Liver Disease, University Health Network, Toronto, Canada \\ ${ }^{4}$ Eli Lilly and Company, Indianapolis, IN, USA \\ ${ }^{5}$ Division of Antiviral Products, Center for Drug Evaluation and Research, US Food and Drug Administration, Silver Spring, MD, USA \\ ${ }^{6}$ Gilead Sciences, Foster City, CA, USA \\ ${ }^{7}$ Hepatitis B Foundation, Doylestown, PA, USA \\ ${ }^{8}$ Roche Products, Welwyn Garden City, UK \\ ${ }^{9}$ Arbutus Biopharma Inc., Warminster, PA, USA \\ ${ }^{10}$ Forum for Collaborative Research, University of California, Berkeley \\ ${ }^{11}$ Arrowhead Pharmaceuticals, Inc, Pasadena, CA, USA \\ ${ }^{12}$ Janssen Research \& Development, Janssen Pharmaceutica NV, Beerse, Belgium
}

\section{Correspondence}

Robert J. Fontana, MD, Professor of

Medicine, University of Michigan, 3912

Taubman, Ann Arbor, Ml 48109.

Email:rfontana@med.umich.edu

\section{Present address}

Patricia Mendez, Immunocore,

Conshohocken, PA, USA

Ryan T. Anderson, Mathematica Policy Research, Washington, DC, USA

\section{Funding information}

MEDIAN Technologies; Gilead Sciences;

Hepatitis B Foundation; Arbutus Biopharma;

Aicuris; GlaxoSmithKline; Abbott Molecular;

Altimmune; DDL Diagnostics; ContraVir;

Astra Zeneca; Springbank Pharma;

Novartis; Assembly Biosciences; Arrowhead

\begin{abstract}
Investigational agents that reduce or eliminate covalently closed circular DNA (cccDNA) or enhance host immunity against hepatitis B virus (HBV)-infected hepatocytes are intended to induce a durable off-treatment clearance of hepatitis $B$ surface antigen ( $\mathrm{HBsAg}$ ) (referred to as functional cure). The aim of this paper was to highlight challenges in interpreting liver safety data in clinical trials of these agents when given alone or in combination regimens. The incidence, grading and management of spontaneous serum ALT flares in untreated chronic HBV patients are reviewed along with a summary of serum ALT flares observed during the registration trials for peginterferon and nucleos $(\mathrm{t})$ ide reverse transcriptase inhibitors. Recommendations regarding the detection, management and interpretation of liver safety biomarker data in future clinical trials as well as suggested inclusion and exclusion criteria for phase $1 / 2$ vs phase 3 studies are provided. Criteria to help classify liver safety signals as being due
\end{abstract}

Abbreviations: AFP, Alpha fetoprotein; ALF, Acute liver failure; ALK, Alkaline phosphatase; ALT, Alanine aminotransferase; Anti-HBe, Antibody to hepatitis B e antigen; Anti-HBs, Antibody to hepatitis B surface antigen; AST, Aspartate aminotransferase; BMI, Body mass index; cccDNA, Covalently closed circular DNA; CMV, Cytomegalovirus; CPK, Creatinine phosphokinase; DILI, Drug-induced liver injury; EBV, Epstein-Barr virus; FDA, Food and Drug Administration; GWAS, Genome-wide association study; HBeAg, Hepatitis B e antigen; HBsAg, Hepatitis B surface antigen; HBV, Hepatitis B virus; HCC, Hepatocellular carcinoma; HCV, Hepatitis C virus; HDS, Herbal and dietary supplements; HDV, Hepatitis D virus; HEV, Hepatitis E virus; HIV, Human immunodeficiency virus; NAFLD, Nonalcoholic fatty liver disease; Nrtl, Nucleos(t)ide reverse transcriptase inhibitors; PD, Pharmacodynamic; PK, Pharmacokinetic; PROD, Paritaprevir, ritonavir, ombitasvir and dasabuvir; RUCAM, Rousell Uclaf Causality assessment method; ULN, Upper limit of normal. 
Pharmaceuticals; Roche Molecular Systems; Janssen Pharmaceuticals; PPD; Quest Diagnostics to the intended therapeutic response, emergence of drug-resistant HBV virions, or idiosyncratic drug-induced liver injury are provided along with a review of the role of an expert hepatic adjudication panel in assessing a compound's hepatotoxicity profile. Finally, an algorithmic approach to the differential diagnosis and recommended medical evaluation and management of individual clinical trial patients that develop a liver safety signal is provided along with the rationale to collect and test research blood samples for future mechanistic studies.

\section{KEYWORDS}

antivirals, causality assessment, drug development, HBV, hepatotoxicity

\section{1 | BACKGROUND}

Durable off-treatment clearance of HBsAg with or without anti-HBs seroconversion 48 weeks after discontinuation of therapy in patients with chronic hepatitis $B$ virus (HBV) infection mirrors natural resolution of acute infection and is the current objective of antiHBV therapy. ${ }^{1}$ Referred to as functional cure, the seroclearance of $\mathrm{HBsAg}$ is expected to decrease the risk of developing hepatocellular carcinoma (HCC) and other complications of chronic liver disease. 2 Currently, approved agents for chronic HBV work either through direct suppression of HBV replication [oral nucleos(t)ide reverse transcriptase inhibitors (Nrtls)] or enhancement of the host immune response [eg Interferon (IFN)]. These therapies have been associated with both on treatment and post-treatment serum ALT 'flares' followed by subsequent improvements in serum aminotransferases, markers of HBV replication and liver histology in some patients. ${ }^{3}$ However, the rate of $\mathrm{HBsAg}$ loss or seroconversion to anti-HBs during or after treatment with currently approved agents remains low $(<1 \% / y) .^{4}$

Over 40 investigational agents with varying mechanisms of action that help reduce or eliminate covalently closed circular DNA (cccDNA) and/or stimulate host immunity against HBV-infected hepatocytes are in development for the treatment of chronic HBV. ${ }^{5}$ To achieve high rates of HBsAg loss, a combination of drugs with complementary mechanisms of action will likely be required. ${ }^{2}$ Many of the current clinical trials aim for a finite duration of therapy followed by a post-treatment follow-up period to assess sustained response. Appropriate interpretation and management of serum ALT elevations during and after treatment, including differentiation between drug-induced liver injury (DILI), viral replication-induced flares and host-induced flares is paramount to the successful evaluation of these regimens while ensuring patient safety (Table 1).

Some of the challenges in interpreting liver safety data in ongoing studies of investigational agents for chronic HBV are highlighted in this paper. First, the frequency and severity of spontaneous serum ALT flares in untreated chronic HBV patients are reviewed. Second, serum ALT flares are categorized into those that reflect therapeutic responses to the study drug vs the emergence of drugresistant virions during treatment, or a resurgence of viral activity after treatment discontinuation. To provide perspective, a synopsis of the liver safety signals observed during the registration trials of currently approved first-line Nrtls and Peg-IFN are reviewed. Third, we describe the incidence, phenotype and methods to establish a potential diagnosis of idiosyncratic DILI. Finally, recommendations for liver safety assessment and management in future studies of virally suppressed and treatment naïve chronic HBV patients receiving investigational agents are provided.

\section{2 | SPONTANEOUS SERUM ALT FLARES IN UNTREATED CHB}

Chronic HBV infection is characterized by a dynamic interplay between the host immune response and replication of the viral genome. The natural history of chronic HBV is often accompanied by spontaneous increases in serum ALT levels termed 'ALT flares' reflecting intra-hepatic necroinflammatory activity resulting from an expanded number of HBV specific T lymphocytes. Therefore, ALT flares signify immune-mediated destruction of infected hepatocytes and frequently occur in association with surges in viral replication. ${ }^{6}$ Serum ALT level is used as a widely available, noninvasive measure of disease activity in untreated chronic HBV patients. Prior studies have demonstrated a moderate correlation between the level of serum ALT elevation and degree of hepatic inflammation on liver biopsy in untreated patients. ${ }^{7,8}$

A uniform laboratory definition of a spontaneous serum ALT flare in chronic HBV is lacking. Initially, flares were defined as an abrupt elevation of serum ALT exceeding $300 \mathrm{U} / \mathrm{L}$ in patients with a baseline serum ALT level of $<200 \mathrm{U} / \mathrm{L}$, ${ }^{9}$ or by an abrupt elevation of serum ALT to $>5 \times$ upper limit of normal (ULN) or an increase $>3$-fold baseline. More recently, an ALT flare has been defined as an ALT level $>10 \times$ ULN and more than twice the baseline value. ${ }^{10}$ All these definitions characterize flares as an abrupt ALT elevation commonly associated with an antecedent or simultaneous rise in serum HBV DNA (Table S1).

In persons who acquire chronic HBV infection early in life, ALT flares become more common during adulthood when patients transition from a phase of $\mathrm{HBeAg}$-positive status (immune tolerant) to 


\begin{tabular}{|c|c|c|}
\hline Flare type & Timing \& characteristics & Clinical sequelae and actions \\
\hline Host mediated & $\begin{array}{l}\text { Spontaneous- enhanced } \\
\text { host immunity to infected } \\
\text { hepatocytes; frequently } \\
\text { preceded by surge in HBV } \\
\text { replication; variable ALT } \\
\text { Treatment related- enhanced } \\
\text { host immunity to infected } \\
\text { hepatocytes } \\
\text { Early <12 wk; variable ALT } \\
\text { Late }>12 \mathrm{wk} \text {; variable ALT }\end{array}$ & $\begin{array}{l}\mathrm{HBeAg} \text { (or } \mathrm{HBsAg} \text { ) loss in some; se- } \\
\text { vere flare may require rescue NRTI } \\
\text { Early flare associated with } \downarrow \mathrm{HBV} \\
\text { replication; continue therapy if no } \uparrow \\
\text { Bili or INR } \\
\mathrm{HBeAg} \text { (or HBsAg) loss in some; con- } \\
\text { tinue therapy if no } \uparrow \text { Bili or INR }\end{array}$ \\
\hline Virally mediated & $\begin{array}{l}\text { On-Treatment - redetection } \\
\text { of previously suppressed } \\
\text { HBV-DNA } \\
\text { Late >12 wk; variable ALT } \\
\text { Post-treatment: redetection of } \\
\text { HBV-DNA within } 48 \text { wk of } \\
\text { therapy completion }\end{array}$ & $\begin{array}{l}\text { Non-compliance associated with } \\
\text { resurgence of wild-type HBV; may } \\
\text { respond to resumption of } \mathrm{Rx} \\
\text { Drug resistant breakthrough associ- } \\
\text { ated with viral variants } \\
\text { Severe may require rescue NRTI }\end{array}$ \\
\hline $\begin{array}{l}\text { Idiosyncratic drug } \\
\text { toxicity }\end{array}$ & $\begin{array}{l}\text { Timing: may occur at any } \\
\text { time; independent of drug } \\
\text { dose or other host factors } \\
\text { Phenotype: Variable ALT; } \\
\text { some with } \uparrow \text { Alk phos or bili }\end{array}$ & $\begin{array}{l}\text { Variable phenotype makes diagnosis } \\
\text { difficult } \\
\text { Serum ALT }>10 \times \text { ULN or } \uparrow T \text {. bili or } \\
\text { INR require immediate drug d/c } \\
\text { Potentially severe in those with } \\
\text { advanced fibrosis/ cirrhosis }\end{array}$ \\
\hline
\end{tabular}

TABLE 1 Types of serum ALT flares observed in Hepatitis B patients the phase of $\mathrm{HBeAg}$-positive chronic hepatitis (immune active). In this situation, flares may be host-derived rather than virally induced, and although still poorly understood, they are most likely the result of a change in the regulation of viral antigen-specific $T$ cells. ${ }^{11}$ Moderate and severe spontaneous serum ALT flares commonly occur coincident to, or immediately after, an increase in serum HBV DNA levels. ${ }^{12}$

Several reviews have reported that spontaneous flares in untreated chronic HBV patients are often associated with an increase in host-derived immunity towards infected hepatocytes which in some cases can be associated with a decrease in viral parameters. ${ }^{13}$ Although ALT flares occur in both untreated HBeAg-positive and $\mathrm{HBeAg-negative} \mathrm{patients,} \mathrm{spontaneous} \mathrm{flares} \mathrm{are} \mathrm{more} \mathrm{frequently}$ observed in $\mathrm{HBeAg}$-positive patients, with an annual incidence of $5 \%-10 \%$. A recent paper from the Hepatitis B Research Network indicates that men, patients who consume alcohol, and those subjects with a higher HBV DNA level were at greatest risk of developing a spontaneous serum ALT flare. ${ }^{14}$ The development of precore and basal core promoter variants is frequently associated with periodic flares of liver cell necrosis interspersed with periods of normal serum ALT and low serum HBV DNA levels. ${ }^{15}$ Flares in $\mathrm{HBeAg}$-negative patients have thus been mainly attributed to increases in the concentration of these mutants in the liver and changes in the ratio of mutant to wild-type HBV. The levels of HBV DNA, HBeAg and/or HBsAg may decrease following the enhanced elimination or suppression of $\mathrm{HBV}$, with $\mathrm{HBeAg}$ seroconversion observed in approximately $30 \%$ of patients. ${ }^{16}$ Following the transition to the inactive phase, $\mathrm{HBsAg}$ seroclearance is reported at an annual rate of $0.7 \%-2.4 \% .^{12}$

\section{3 | SERUM ALT FLARES IN CHB PATIENTS RECEIVING CURRENTLY APPROVED ANTIVIRAL TREATMENT}

Four types of serum ALT elevations were noted in clinical trials of IFNs and Nrtls in chronic HBV patients: (a) spontaneous pretreatment flares; (b) early on treatment flares, typically in the first 12 weeks of treatment; (c) later on treatment flares between week 12 and end of treatment; and (d) post-treatment flares. Serum ALT elevations occurring after the screening visit but before the first dose of study drug (during the baseline visit) presumably correspond to the spontaneous flare activity that is part of the natural history of untreated CHB infection. Other situations where elevations in ALT may occur, such as treatment with immunosuppressive agents, pregnancy (mainly post-partum), co-infection with hepatitis $C$ or $D$ viruses, and development of de novo HCC are outside the scope of this review.

\subsection{Early on treatment serum ALT Flares}

In the first few months of Nrtl or Peg-IFN therapy, some patients with rapid treatment-induced suppression of HBV replication experience transient increases in serum ALT which usually resolve despite continued treatment. These likely reflect a treatment-induced enhancement of immune-mediated cytolysis of HBV-infected liver cells (Table 2). Although close patient monitoring to evaluate alternative causes of the ALT elevations occasionally uncovered an acute intercurrent viral infection or toxin exposure, most of these flares were associated with marked early efficacy responses (Figure 1A). Importantly, these patients typically exhibited stable serum albumin, 


\section{Tenofovir disproxil fumarate}

\begin{tabular}{|c|c|c|c|}
\hline \multirow[b]{2}{*}{ Maximum ALT elevation } & & \multicolumn{2}{|c|}{$\begin{array}{l}\text { Number with abnormality/ } \\
\text { number tested (\%) }\end{array}$} \\
\hline & & $\begin{array}{l}\mathrm{HBeAg}(+) \\
\mathrm{N}=524\end{array}$ & $\begin{array}{l}\mathrm{HBeAg}(-) \\
\mathrm{N}=441\end{array}$ \\
\hline \multirow[t]{4}{*}{$>1$ to $\leq 3 \times$ ULN } & Baseline & $295(56.3)$ & $276(62.6)$ \\
\hline & On-treatment: $\leq 12 \mathrm{wk}$ & $262(50.0)$ & $254(57.6)$ \\
\hline & Year 1 & $290(55.3)$ & $205(46.5)$ \\
\hline & Year 2 & $198(37.8)$ & 139 (31.5) \\
\hline \multirow[t]{4}{*}{$>3$ to $\leq 5 \times$ ULN } & Baseline & $107(20.4)$ & $61(13.8)$ \\
\hline & On-treatment: $\leq 12 \mathrm{wk}$ & $105(20.0)$ & 49 (11.1) \\
\hline & Year 1 & $39(7.4)$ & $10(2.3)$ \\
\hline & Year 2 & $15(2.9)$ & $7(1.6)$ \\
\hline \multirow[t]{4}{*}{$>5$ to $\leq 10 \times$ ULN } & Baseline & $68(13.0)$ & $47(10.7)$ \\
\hline & On-treatment: $\leq 12 \mathrm{wk}$ & $77(14.7)$ & $24(5.4)$ \\
\hline & Year 1 & $13(2.5)$ & $0(0.0)$ \\
\hline & Year 2 & $2(0.4)$ & $3(0.7)$ \\
\hline \multirow[t]{4}{*}{$>10 \times$ ULN } & Baseline & $22(4.2)$ & $8(1.8)$ \\
\hline & On-treatment: $\leq 12 \mathrm{wk}$ & $35(6.7)$ & $8(1.8)$ \\
\hline & Year 1 & $2(0.4)$ & $0(0.0)$ \\
\hline & Year 2 & $1(0.2)$ & $1(0.2)$ \\
\hline \multicolumn{4}{|l|}{ Peginterferon alpha-2a } \\
\hline & & \multicolumn{2}{|c|}{$\begin{array}{l}\text { Number with abnormality/ } \\
\text { number tested (\%) }\end{array}$} \\
\hline & & $\mathrm{HBeAg}(+)$ & $\mathrm{HBeAg}(-)$ \\
\hline Maximum ALT elevation & & $N=481$ & $N=330$ \\
\hline \multirow[t]{4}{*}{$>1$ to $\leq 3 \times$ ULN } & Baseline & $229(47.6)$ & $217(65.8)$ \\
\hline & On-treatment: $\leq 12 \mathrm{wk}$ & $175(36.4)$ & $136(41.2)$ \\
\hline & On-treatment (48 wk) & $149(31.0)$ & $134(40.6)$ \\
\hline & Post-treatment ${ }^{b}$ & $188(39.1)$ & $132(40.0)$ \\
\hline \multirow[t]{4}{*}{$>3$ to $\leq 5 \times$ ULN } & Baseline & $117(24.3)$ & $80(20.7)$ \\
\hline & On-treatment: $\leq 12 \mathrm{wk}$ & $131(27.2)$ & $73(22.1)$ \\
\hline & On-treatment (48 wk) & $129(26.8)$ & 77 (23.3) \\
\hline & Post-treatment ${ }^{b}$ & 55 (11.4) & $42(12.7)$ \\
\hline \multirow[t]{4}{*}{$>5$ to $\leq 10 \times$ ULN } & Baseline & $89(18.5)$ & 49 (12.7) \\
\hline & On-treatment: $\leq 12 \mathrm{wk}$ & $120(25.0)$ & $58(17.6)$ \\
\hline & On-treatment (48 wk) & $139(28.9)$ & $68(20.6)$ \\
\hline & Post-treatment ${ }^{b}$ & $67(13.9)$ & $32(9.7)$ \\
\hline \multirow[t]{4}{*}{$>10 \times$ ULN } & Baseline & $22(4.57)$ & $10(2.6)$ \\
\hline & On-treatment: $\leq 12 \mathrm{wk}$ & $43(8.9)$ & $26(7.9)$ \\
\hline & On-treatment (48 wk) & $57(11.9)$ & $32(9.7)$ \\
\hline & Post-treatment ${ }^{\mathrm{b}}$ & $43(8.9)$ & $31(9.4)$ \\
\hline
\end{tabular}

${ }^{a}$ Data obtained from registration trials of Peg-IFNa2a and TDF that enrolled immune active hepatitis B patients with elevated ALT levels at baseline. The absolute frequency of ALT elevations has been reported for each period with no analysis in comparison with the individual patient's baseline level (i.e no assessment of treatment-emergent ALT elevations).

${ }^{\mathrm{b}}$ Post-treatment period of $24 \mathrm{wk}$.
TABLE 2 Incidence of serum ALT elevations in Hepatitis B patients receiving oral Nrtls and PegIFN in registration trials ${ }^{\mathrm{a}}$ 


\section{(A) On-treatment flare}

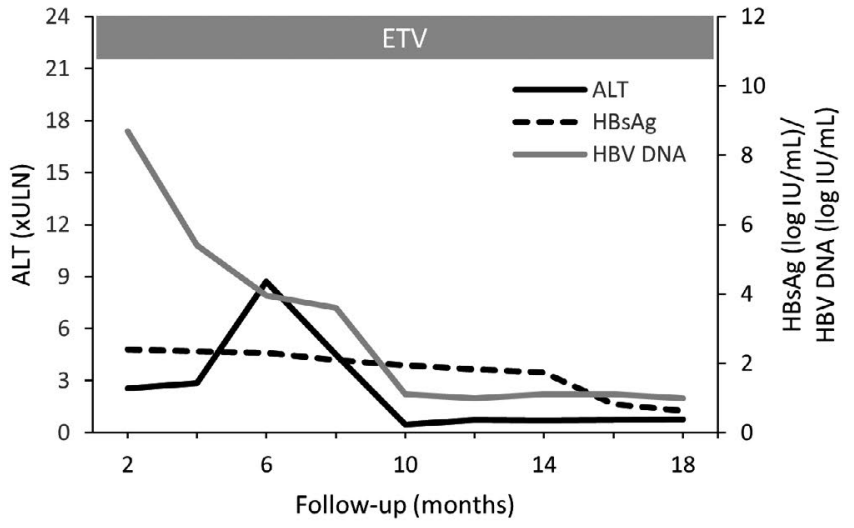

(C) Post-treatment flare

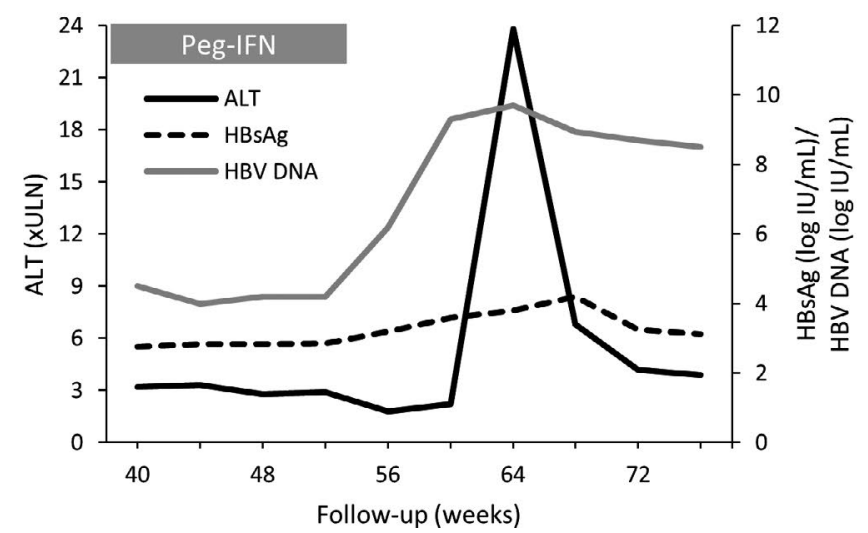

\section{(B) Resistance-induced flare}

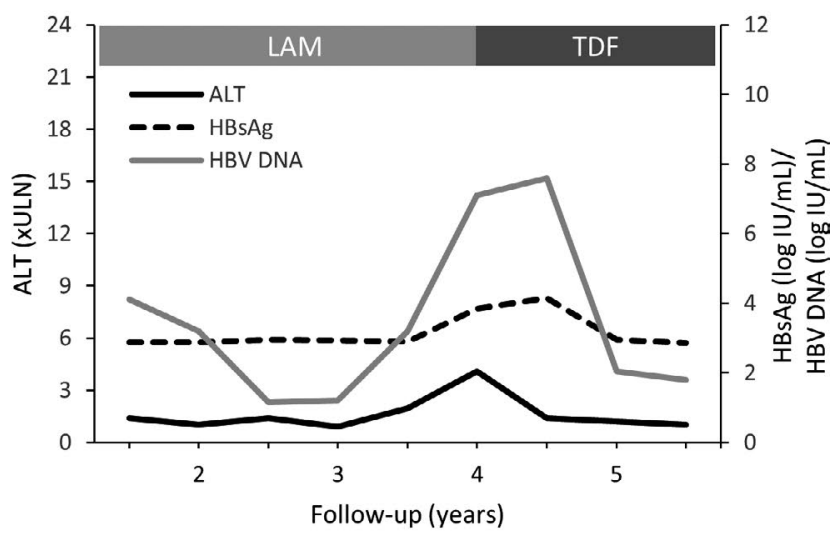

FIGURE 1 Types of serum ALT flares in CHB patients receiving approved antiviral treatments. A, A patient with chronic HBV developed a moderate serum ALT flare at month 6 of entecavir therapy that was self-limited and resolved despite continued dosing. B, This patient developed drug resistance to lamivudine with an increase in HBV DNA that preceded the mild ALT flare. The introduction of tenofovir led to a reduction in serum HBV DNA and normalization of serum ALT levels. C, Following completion of a 48-week course of peginterferon, this patient experienced a rise in serum HBV DNA levels that was associated with a severe ALT flare but no loss of $\mathrm{HBs} A g$

INR and bilirubin levels during the ALT flare, which helped differentiate these early flare events from severe liver inflammation with compromise of liver function or clinically important DILI. Patients with early ALT flares in the absence of other liver parameter abnormalities and who had persistently suppressed or declining levels of HBV DNA could usually continue study treatment uninterrupted and resume their normal schedule of clinic visits after documentation of stable hepatic functions and persistently declining ALT levels to less than half of their peak 'flare' values. In addition to changes in serum HBV DNA levels, a number of quantitative exploratory viral biomarkers [ie HBV RNA, quantitative $\mathrm{HBsAg}, \mathrm{HBeAg}$ and $\mathrm{HB}$ core-related antigen ( $\mathrm{HBcrAg})$ ] show promise to help differentiate patients who are experiencing immune reconstitution with cytolysis of HBV-infected hepatocytes from DILI, but further development is needed. ${ }^{17}$

\section{2 | Late on treatment serum ALT flares}

Serum ALT elevations occurring after 12 weeks of treatment in Peg-IFN and first-generation Nrtl studies generally occurred in the setting of imminent $\mathrm{HBeAg}$ or $\mathrm{HBsAg}$ seroclearance or with the emergence of drug-resistant variants for Nrtl. The majority of PegIFN treated patients (>85\%) have elevated ALT levels throughout the 48-week treatment period (with normal levels of bilirubin, INR and albumin), although the incidence of higher grades ( $>5 \times$ ULN) of ALT elevation is lower after 12 weeks compared with the initial 12 weeks (Table 2). The increase in viral replication after months of treatment often reflected the development of viral resistance (especially for older $\mathrm{Nrtl}$ agents with lower barriers to resistance) or patient noncompliance with increasing levels of serum HBV DNA (Figure 1B).

\section{3 | Post-treatment serum ALT flares}

Potentially severe post-treatment serum ALT flares were noted in studies of Peg-IFN and in the early Nrtl studies (Figure 1C). ${ }^{18,19}$ Posttreatment flares are attributed to memory T-cell responses to recrudescent HBV replication with rising HBV DNA levels in a subset of the patients who had not achieved $\mathrm{HBeAg} / \mathrm{HBsAg}$-seroconversion during treatment. ${ }^{20}$ Such events usually present soon after end 
of treatment but can occur later (ie 24-48 weeks) after treatment discontinuation and may be clinically severe in some instances with occasional progression to liver failure, especially in patients with cirrhosis. ${ }^{21}$ Although the frequency and severity of post-therapy flares may vary with HBV genotype as well as the oral agent that is discontinued, these episodes are essentially indistinguishable from the spontaneous flares seen in untreated $\mathrm{CHB}$ patients. ${ }^{22,23}$ If clinically significant hepatitis develops with confirmed rising HBV DNA levels after treatment withdrawal, it is important to resume HBV suppressive therapy expeditiously. To monitor for such events in clinical trials, a post-treatment monitoring phase of at least 48 weeks is now recommended by the FDA. ${ }^{24}$ Early experience with post-treatment flares suggested that severe flares could be averted when antiviral treatment was promptly reinstituted with either the study drug or approved Nrtl. ${ }^{13}$

More recent studies have explored the utility of discontinuing Nrtls in noncirrhotic HBeAg-negative patients who have been stably suppressed for prolonged periods of time. ${ }^{25,26}$ In a pilot, randomized study of 42 European chronic HBV patients with genotype $D$ infection that had been suppressed on tenofovir for $>4$ years, $19 \%$ (4 of 22) achieved HBsAg loss after tenofovir discontinuation, with a further $43 \%$ able to remain off therapy with suppressed HBV DNA and normal ALT at 144 weeks after therapy cessation. ${ }^{23}$ However, studies of Asian patients with primarily genotype $\mathrm{B}$ and $\mathrm{C}$ chronic HBV infection have demonstrated a much lower rate of $\mathrm{HBsAg}$ seroclearance and a higher rate of antiviral therapy resumption after $\mathrm{Nrtl}$ discontinuation. ${ }^{27-29}$ Furthermore, whether pretreatment or end of treatment quantitative HBsAg or HBV RNA levels may predict the likelihood of post-therapy seroclearance remains unclear. Nonetheless, most experts advise against NRTI discontinuation in any $\mathrm{CHB}$ patient with cirrhosis due to safety concerns until future prospective studies reliably identify patients that are likely to benefit from treatment discontinuation. ${ }^{30}$

\section{4 | IDIOSYNCRATIC DILI WITH INVESTIGATIONAL AGENTS}

Cases of DILI have been reported with most of the 900 drugs approved by the Food and Drug Administration (FDA) and with a multitude of herbal and dietary supplements. ${ }^{31,32}$ DILI may present with distinct clinical, laboratory and histological manifestations presumably due to differing mechanisms of hepatotoxicity. ${ }^{33}$ Generally, the development of idiosyncratic DILI does not usually correlate with the dose or duration of suspect drug used or known effects of the drug identified during preclinical toxicology studies or early human pharmacokinetic (PK) studies. Nonetheless, heightened DILI risk may occur if a certain level of drug exposure or duration of treatment has been exceeded. Because these DILI reactions are idiosyncratic, they depend on increased host susceptibility that may reflect inter-individual variations in drug metabolism, immune responses or susceptibility to off-target toxicological effects.
In clinical trials of patients without pre-existing liver disease, hepatocellular DILI may be suspected whenever a drug-exposed patient experiences an increase in their serum ALT levels to $>3 \times$ ULN or from their baseline values during or soon after treatment for which there is no other plausible cause identified. Given that $\mathrm{CHB}$ has a high underlying rate of serum ALT elevations, distinguishing DILI due to an investigational agent from an HBV-related cause of ALT increase is always challenging. In other instances, DILI due to an investigational agent may lead to a predominant increase in serum alkaline phosphatase (ALK) levels to $>2 \times$ ULN and/or an increase in total bilirubin to $>2 \times$ ULN or $2.5 \mathrm{mg} / \mathrm{dL}$, consistent with a cholestatic form of injury. In patients without underlying liver disease, drug-induced acute cholestatic injuries typically do not progress to acute liver failure (ALF). Nonetheless, cholestatic injuries in certain patients with underlying liver disease or cirrhosis may be associated with substantial clinical worsening, and in some instances, hepatic decompensation or death ${ }^{34}$ (see Text S1).

Establishing a diagnosis of DILI requires a methodical approach that must exclude other more common causes of liver injury. Currently, there is no objective laboratory biomarker to unequivocally establish that an episode of liver injury is due to a drug vs another more common cause of liver injury such as alcohol, viral hepatitis or pancreatobiliary disease. ${ }^{35}$

\subsection{Causality assessment in clinical trials}

Causality assessment of DILI in clinical trials is most commonly based on expert opinion. Individuals with recognized expertise in the evaluation of DILI conduct a comprehensive review of liver injury cases of interest, scoring each of them on an ordinal scale of likelihood of causal association with the study drug that vary from $>95 \%$ (definite) to unlikely (<25\%). This approach permits accounting for extrahepatic features such as the presence of fever, rash or eosinophilia that make DILI more likely ${ }^{36}$ whereas serum CPK, hepatitis serologies or liver imaging can help determine whether an alternative cause of liver injury is more likely. Expert opinion can also incorporate known pharmacological attributes of the study drug such as a prolonged serum or biological half-life of the suspect drug, as well as histopathologic correlates if biopsy data are available. Finally, experts will consider underlying complexities in the patient population being studied that may impact liver test findings such as the high prevalence of hepatic macrovesicular steatosis and abnormal liver biochemistry profiles in patients with diabetes mellitus receiving an investigational agent. ${ }^{36}$

The United States Drug-Induced Liver Injury Network (DILIN) has proposed a five-point categorical scale to grade the severity of a suspected DILI episode varying from 1) asymptomatic laboratory abnormalities to 5) representing death or the need for liver transplantation. ${ }^{37}$ The late Hyman Zimmerman noted that the development of jaundice (ie total bilirubin $>2.5 \mathrm{mg} / \mathrm{dL}$ ) in patients with acute hepatocellular liver injury defined as a serum ALT $>3 \times$ ULN caused by a drug is associated with an estimated mortality of $10 \% .^{38}$ This observation (known as Hy's law) has been retrospectively confirmed in post-marketing surveillance studies of patients with drug-induced 
hepatocellular injury associated hyperbilirubinemia. ${ }^{39}$ When present, Hy's Law cases have proven to be of value to identify drugs that have substantial hepatotoxicity liability and a significant potential to cause ALF post-marketing. ${ }^{40}$

\section{5 | RECOMMENDATIONS FOR LIVER SAFETY ASSESSMENT IN HEPATITIS B CLINICAL TRIALS}

\section{1 | Baseline and reference ALT values}

The degree of serum ALT elevation along with the HBV replicative status of the patient is used to guide the decision to initiate conventional antiviral treatment in chronic HBV. To help standardize clinical management, the AASLD recommends an ULN for serum ALT of $35 \mathrm{U} / \mathrm{L}$ for males and $25 \mathrm{U} / \mathrm{L}$ for females. ${ }^{3}$ Since many chronic HBV patients being considered for enrolment into clinical trials will have elevated serum ALT levels, it is necessary to compare treatment-emergent ALT elevations to a patient's baseline or nadir values. In addition to varying by patient age and sex, the ULN values for serum ALT and other liver safety biomarkers are known to vary among laboratories due to differences in reference populations and analytical variation among commercial assays. ${ }^{41}$ Since serum ALT levels may fluctuate substantially over short periods of time, the serum ALT value at screening may not accurately represent the patient's true baseline value, defined as the last ALT taken before the first dose of study drug (Table 3). Registration trials of IFNs and Nrtls for chronic HBV studied immune active patients where the majority of patients had elevated ALT levels at baseline (Table 2). ${ }^{42,43}$ In general, the majority of the screening and pretreatment baseline serum ALT values are anticipated to be lower or normal in Nrtl-suppressed patients than in treatment naïve or experienced patients not receiving an antiviral drug. It is recommended that the serum ALT value obtained at the baseline visit, immediately prior to dosing be used as the reference value for further assessment of ALT changes on treatment rather than the ALT value obtained at the screening visit. If the baseline serum ALT level is significantly elevated compared with the screening ALT level (ie $>2 \times$ screening level), an evaluation for possible alternative aetiologies of abnormal liver tests is advisable prior to initiation of study treatment.

Serum ALT levels usually decrease during effective antiviral therapy. The use of on treatment nadir serum ALT values as the postbaseline adjusted ALT values for 'flare' evaluations was employed in previous Nrtl trials in chronic HBV patients as well as HCV drug development with direct-acting oral antiviral agents. ${ }^{44,45}$ Therefore, we recommend that the on treatment nadir ALT value be used as a reference for identifying a serum ALT flare during treatment and follow-up.

\section{2 | Inclusion and exclusion criteria for clinical trials of investigational agents}

Inclusion and exclusion criteria may need to be adjusted on a caseby-case basis according to the targeted patient population, and the mechanism(s) of action, PK/PD considerations and the preclinical safety profile of the investigational agent. In studies enrolling $\mathrm{Nrtl}$-suppressed patients, patients treated for a minimum of 6 months with a single Nrtl should consistently have HBV DNA levels below the lower limit of quantitation (and ideally undetectable HBV DNA) on at least 2 separate tests using a quantitative PCR-based assay. ${ }^{1}$

\section{3 | Liver disease severity and other considerations}

A thorough medical history, physical examination and serology tests for HCV, hepatitis D (HDV) and HIV infection at screening will help exclude patients with competing causes of liver disease. Patients who do not have a liver imaging study within 6 months of enrolment should have one at the time of screening to exclude HCC and concomitant pancreatobiliary disease. Investigational agents for $\mathrm{CHB}$ with new mechanisms of action should not be evaluated in patients with advanced fibrosis/cirrhosis until initial proof of efficacy and safety have been demonstrated in patients with less advanced liver disease (Table 3). Generally, this will not be available until phase $2 \mathrm{~b}$ studies have been completed. Although a liver stiffness score of $>9 \mathrm{kPa}$ is frequently used to exclude chronic HBV patients with advanced fibrosis, the optimal cutoff value may be higher in those receiving oral antiviral therapy and lower in those with underlying hepatic steatosis. ${ }^{46-48}$

\subsection{Clinical Trials in hepatitis B patients with HDV or HIV co-infection}

An estimated 10-20 million chronic HBV patients worldwide have HDV co-infection and are at increased risk for accelerated liver disease progression. ${ }^{49}$ Investigational regimens aimed at functional cure for HDV co-infected patients may include agents targeting the HDV virus, the HBV virus or host immune response to infected hepatocytes. ${ }^{50}$ Interpretation of liver safety biomarker data in these studies will require simultaneous assessment of both HBV and HDV efficacy biomarkers such as anti-HDV IgM, anti-HDV IgG and HDV-RNA levels. Similarly, clinical studies targeting the 30 million HIV co-infected CHB patients will also need to include assessment of HIV viral parameters such as HIV RNA levels and $\mathrm{CD}^{4}$ counts. ${ }^{51}$ Furthermore, interpretation of liver safety biomarker data will need to account for the potential of an immune reconstitution syndrome in HIV patients recently started on antiretroviral therapy, potential hepatic mitochondrial damage from the antiretroviral regimen and the higher incidence of pre-existing liver disease in HIV co-infected patients. $^{52}$

\section{5 | Pretreatment liver safety biomarker exclusion criteria}

For treatment naïve or nonresponders to a previous treatment, chronic HBV patients with a screening serum ALT level > 7× ULN or $>300 \mathrm{U} / \mathrm{L}$ are recommended for exclusion. For Nrtl-suppressed 
TABLE 3 Recommended exclusion criteria and laboratory monitoring in chronic hepatitis B Clinical Trial patients

\begin{tabular}{|c|c|}
\hline Topic & Exclusion criteria $^{a}$ \\
\hline $\begin{array}{l}\text { Other causes of liver } \\
\text { disease }\end{array}$ & $\begin{array}{l}\text { - Anti-HCV (+) with detectable HCV RNA, anti-HDV (+), or anti-HIV } \\
(+) \\
\text { - Evidence of other causes of liver injury via liver biopsy, serological } \\
\text { tests, liver imaging (ultrasound, CT scan or MRI), or medical history }\end{array}$ \\
\hline $\begin{array}{l}\text { Known or suspected } \\
\text { hepatocellular } \\
\text { carcinoma (HCC) }\end{array}$ & $\begin{array}{l}\text { - Prior history of HCC } \\
\text { - Imaging study demonstrating solid mass c/w HCC } \\
\text { - Serum AFP }>100 \mathrm{ng} / \mathrm{mL} \text { independent of liver imaging results } \\
\text { - If serum AFP }>\text { ULN but }<100 \text {, must have CT/ MRI with contrast } \\
\text { showing no evidence of HCC }\end{array}$ \\
\hline $\begin{array}{l}\text { Liver disease } \\
\text { severity }\end{array}$ & $\begin{array}{l}\text { Phase 1-2: } \\
\text { Advanced fibrosis/ cirrhosis (any CTP score) established by any of the } \\
\text { following: } \\
\text { - Liver biopsy showing cirrhosis } \\
\text { - Imaging evidence of suspected cirrhosis } \\
\text { - } \text { Fibroscan stiffness score }>9-12 \mathrm{kPa}^{c} \\
\text { Laboratory evidence suggestive of advanced disease including plate- } \\
\text { lets }<100000 / \mathrm{mL}, \mathrm{T} \text { Bili }>1.5 \times \mathrm{ULN} \text {, albumin }<3.4 \mathrm{~g} / \mathrm{dL} \text { or INR }>1.2 \\
\text { Phase } 3 \text { : } \\
\text { - } \text { CTP B or C cirrhosis } \\
\text { - } \text { T Bili }>2 \times \text { ULN }\end{array}$ \\
\hline $\begin{array}{l}\text { Serum ALT, } \\
\text { Alk P, } \\
\text { HBV DNA }\end{array}$ & $\begin{array}{l}\text { NRTI suppressed: } \\
\text { - Serum ALT }>3 \times \text { ULN or }>120 \mathrm{U} / \mathrm{L} \text {, or } \\
\text { - } \text { ALK }>2 \times \text { ULN, or } \\
\text { - } \text { HBV DNA > LLD within } 6 \text { mo of screening } \\
\text { Treatment naïve or nonresponders: } \\
\text { - Serum ALT }>7-10 \times \text { ULN or }>300 \mathrm{U} / \mathrm{L} \text {, or } \\
\text { - } \quad \text { ALK }>2 \times \text { ULN }\end{array}$ \\
\hline Study phase & Recommended laboratory monitoring \\
\hline Phase 1 and $2 a$ & $\begin{array}{l}\text { - Monitor liver safety biomarkers (serum ALT, AST, ALK, T Bili, INR } \\
\text { and albumin) every 1-2 wk during first month of treatment, monthly } \\
\text { thereafter on-treatment and at week } 4,8,12,24 \text { and } 48 \text { after } \\
\text { dosing }\end{array}$ \\
\hline Phase $2 b$ and 3 & $\begin{array}{l}\text { - Monitor liver safety biomarkers every } 2-4 \text { wk in the first } 3 \text { mo and } \\
\text { every 4-8 wk thereafter during dosing and at week } 4,8,12,24 \text { and } \\
48 \text { after dosing } \\
\text { - In drugs with suspected hepatotoxicity }{ }^{d} \text {, monitor liver safety bio- } \\
\text { markers every } 2-4 \text { wk for the first } 6 \text { mo and every } 4-8 \text { wk thereafter }\end{array}$ \\
\hline
\end{tabular}

${ }^{a}$ Specific exclusion criteria may vary based upon the mechanism of action and safety information from preclinical and early clinical studies.

${ }^{\mathrm{b}}$ For example, tests to exclude genetic hemochromatosis, autoimmune hepatitis, and alcoholic liver disease.

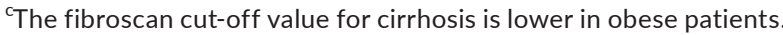

${ }^{\mathrm{d}}$ Based upon preclinical data, available clinical trial data, and drug pharmacokinetics/mechanism of action AFP, alpha fetoprotein; ALT, alanine aminotransferase; CTP, Child-Turcotte-Pugh; DILI, drug induced liver injury HCC, hepatocellular carcinoma; INR, international normalized ratio; LLD, lower limit of detection; PLT, platelets; T Bili, total bilirubin. patients those with a serum ALT level $>3 \times$ ULN or $>120 \mathrm{U} / \mathrm{L}$ should be considered for exclusion since the majority of $\mathrm{Nrtl}$-suppressed adult patients have a normal or near normal ALT. ${ }^{53}$ Since most patients with chronic HBV have a normal or near normal ALK level, any patient with a serum ALK level $>2 \times$ ULN is recommended for exclusion as this is suggestive of an additional cause of liver injury. For the purpose of a clinical trial, the ULN values provided by the central laboratory should be employed rather than ULN values suggested by various guidelines or consensus papers.

\section{6 | RECOMMENDED EVALUATION OF HEPATITIS B PATIENTS WITH A LIVER SAFETY SIGNAL DURING CLINICAL TRIALS}

Given the diversity in mechanism of action of the newer agents, it is difficult and perhaps not advisable to develop recommendations that are too specific and/or restrictive to cover all potential clinical trial scenarios. While no drugs are completely risk-free, the balance between potential harm vs benefit needs to be carefully assessed. Acute and significant serum ALT flares should always be of concern 
TAB LE 4 Recommended management of liver safety signals in clinical trials of NRTI suppressed Hepatitis B patients

\begin{tabular}{|c|c|c|c|}
\hline $\begin{array}{l}\text { Treatment emergent ALT } \\
\text { elevation }\end{array}$ & $\begin{array}{l}\text { Treatment emergent total/direct } \\
\text { bilirubin elevation }^{\text {a }}\end{array}$ & Liver-related symptoms & Action \\
\hline $\begin{array}{l}\text { Normal baseline: } \\
\text { ALT } \geq 5 \times \text { ULN } \\
\text { Elevated baseline }{ }^{\text {b. }} \\
\text { ALT } \geq 3 \times \text { baseline (or } \geq 3 \times \\
\text { new nadir') or } \geq 300 \mathrm{U} / \mathrm{L} \\
\text { (whichever occurs first) }\end{array}$ & $\begin{array}{l}\text { Normal } \\
\text { Patients with Gilbert's syndrome: No } \\
\text { change in baseline TBL }\end{array}$ & None & $\begin{array}{l}\text { Repeat ALT, AST, ALP, TBL, INR, albumin, } \\
\text { obtain HBV DNA }{ }^{d} \text { within 3-5 d and initi- } \\
\text { ate close monitoring } \text { until levels return } \\
\text { toward nadir values } \\
\text { Evaluate for etiology of ALT elevation } \\
\text { (Table 6) }\end{array}$ \\
\hline $\begin{array}{l}\text { Normal baseline: } \\
\text { ALT } \geq 8 \times \text { ULN } \\
\text { Elevated baseline }^{\text {b. }} \\
\text { ALT } \geq 5 \times \text { baseline (or } \geq 5 \times \\
\text { new nadir } \text { ) or } \geq 500 \mathrm{U} / \mathrm{L} \\
\text { (whichever occurs first) }\end{array}$ & $\begin{array}{l}\text { Normal } \\
\text { Patients with Gilbert's syndrome: No } \\
\text { change in baseline TBL }\end{array}$ & None & $\begin{array}{l}\text { Repeat ALT, AST, ALP, TBL, INR, albumin } \\
\text { and obtain HBV DNA }{ }^{\mathrm{d}} \text { in } 2-3 \mathrm{~d} \text {. If ab- } \\
\text { normality persists, consider interrupting } \\
\text { study drug and initiate close monitoring } \\
\text { until levels return toward nadir values. } \\
\text { Evaluate for etiology of ALT elevation } \\
\text { (Table 6). Study drug can be restarted } \\
\text { only if a self-limited non-drug etiology is } \\
\text { identified }\end{array}$ \\
\hline $\begin{array}{l}\text { Normal baseline: } \\
\text { ALT } \geq 3 \times \text { ULN } \\
\text { Elevated baseline } e^{\text {b. }} \\
\text { ALT } \geq 2 \times \text { baseline (or } \geq 2 \times \\
\text { new nadir }{ }^{\text {c }} \text { or } \geq 300 \mathrm{U} / \mathrm{L} \\
\text { (whichever occurs first) }\end{array}$ & $\begin{array}{l}\text { Normal } \\
\text { Patients with Gilbert's syndrome: No } \\
\text { change in baseline TBL }\end{array}$ & $\begin{array}{l}\text { Severe fatigue, nausea, } \\
\text { vomiting, right upper } \\
\text { quadrant pain }\end{array}$ & $\begin{array}{l}\text { Immediately interrupt study drug }{ }^{f} \text {. Repeat } \\
\text { ALT, AST, ALP, TBL, INR, albumin and } \\
\text { obtain HBV DNA }{ }^{d} \text { in } 2-3 \text { d. Initiate close } \\
\text { monitoring }{ }^{\text {e }} \text { until levels return toward } \\
\text { nadir values. Evaluate for etiology of ALT } \\
\text { elevation (Table 6). Study drug can be } \\
\text { restarted only if a self-limited non-drug } \\
\text { etiology is identified }\end{array}$ \\
\hline $\begin{array}{l}\text { Normal baseline: } \\
\text { ALT } \geq 3 \text { ULN } \\
\text { Elevated baseline }{ }^{\text {b. }} \\
\text { ALT } \geq 3 \times \text { baseline (or } \geq 3 \times \\
\text { new nadir') or } \geq 300 \mathrm{U} / \mathrm{L} \\
\text { (whichever occurs first) }\end{array}$ & $\begin{array}{l}\text { TBL } \geq 2 \times \text { ULN } \\
\text { Patients with Gilbert's syndrome: } \\
\text { Doubling of direct bilirubin }\end{array}$ & None & $\begin{array}{l}\text { Immediately interrupt study drug }{ }^{f} \text {. Repeat } \\
\text { ALT, AST, ALP, TBL, INR, albumin and } \\
\text { obtain HBV DNA }{ }^{\mathrm{d}} \text { in } 2-3 \mathrm{~d} \\
\text { Initiate close monitoring }{ }^{\mathrm{e}} \text { until levels } \\
\text { return toward nadir values. Evaluate for } \\
\text { etiology of ALT elevation (Table } 8 \text { ). Study } \\
\text { drug can be restarted only if a self-lim- } \\
\text { ited non-drug etiology is identified }\end{array}$ \\
\hline
\end{tabular}

Notes: Modified from reference 45.

Abbreviations: Alb, albumin; ALP, alkaline phosphatase; ALT, alanine aminotransferase; AST, aspartate aminotransferase; TBL, total bilirubin; ULN, upper limit of normal.


and hemolysis versus liver injury.

${ }^{b}$ Elevated baseline is defined as ALT $\geq 1.5 \times$ ULN.

cIn patients with a stable decrease in ALT during treatment ( $>50 \%$ of baseline value), a new baseline, corresponding to the ALT nadir, should be established as reference for subsequent determination of a DILI signal.

${ }^{\mathrm{d}}$ Additional recommended HBV-related tests: quantitative hepatitis B surface antigen (HBsAg quant), quantitative hepatitis B e antigen (HBeAg quant), quantitative hepatitis B surface antibody (anti-HBs quant).

${ }^{\mathrm{e}}$ Frequency of monitoring may need to be adjusted based on clinical scenario and severity of injury.

fDrug interruption and discontinuation decisions should involve assessment for other causes of abnormal hepatic biochemical tests including HBV reactivation as well as the half-life and dosing interval of the investigational agent (see Table 6). In some instances, NRTIs may be continued in patients receiving these agents in combination with an investigational drug.

but understanding the signal in the context of the complex interplay between HBV, the host immune system and the potential direct therapeutic and toxic effects of the drug is paramount to understand the true therapeutic potential of any new treatment under evaluation. Unnecessarily stopping a drug may in itself cause harm. In the paragraphs below, recommendations are given on how to manage and interpret serum ALT flares, in the context of other biomarkers, such as HBV DNA, ALK, total bilirubin and histological data, and will likely need to be adapted to individual agents and development programmes. Both total and direct bilirubin levels should be obtained at baseline and during treatment to differentiate biochemical abnormalities in a patient with unconjugated hyperbilirubinemia associated with Gilbert's syndrome or haemolysis from those that are markers of liver injury.

Frequent monitoring of liver safety biomarkers is recommended for all CHB patients receiving a new investigational agent. ${ }^{54}$ Many patients will likely have serum ALT elevations either during or after treatment that are above their pretreatment baseline or on treatment nadir. The investigator and sponsor will need to make an assessment if the observed rise in serum ALT levels is 
TAB LE 5 Recommended management of liver safety signals in clinical trials of treatment naive or prior nonresponder hepatitis B patients

\begin{tabular}{|c|c|c|c|}
\hline $\begin{array}{l}\text { Treatment emergent ALT } \\
\text { elevation }\end{array}$ & $\begin{array}{l}\text { Treatment emergent total/ direct } \\
\text { bilirubin elevation }^{f}\end{array}$ & Liver-related symptoms & Action \\
\hline $\begin{array}{l}\text { Normal baseline: } \\
\text { ALT } \geq 5 \times \text { ULN } \\
\text { Elevated baseline }^{\text {b: }} \\
\text { ALT } \geq 3 \times \text { baseline (or } \geq 3 \times^{c} \\
\text { new nadir } \text { ) or } \geq 500 \mathrm{U} / \mathrm{L} \\
\text { (whichever occurs first) }\end{array}$ & $\begin{array}{l}\text { Normal } \\
\text { Patients with Gilbert's syndrome: No } \\
\text { change in baseline TBL }\end{array}$ & None & $\begin{array}{l}\text { Repeat ALT, AST, ALP, TBL, INR, albumin, } \\
\text { obtain HBV DNA }{ }^{d} \text { within 3-5 d and initi- } \\
\text { ate close monitoring }{ }^{\mathrm{e}} \text { until levels return } \\
\text { toward nadir values. Evaluate for etiol- } \\
\text { ogy of ALT elevation (Table 6) }\end{array}$ \\
\hline $\begin{array}{l}\text { Normal baseline: } \\
\text { ALT } \geq 8 \times \text { ULN } \\
\text { Elevated baseline }^{\text {b. }} \\
\text { ALT } \geq 5 \times \text { baseline (or } \geq 5 \times^{c} \\
\text { new nadir } \text { ) or } \geq 800 \mathrm{U} / \mathrm{L} \\
\text { (whichever occurs first) }\end{array}$ & $\begin{array}{l}\text { Normal } \\
\text { Patients with Gilbert's syndrome: No } \\
\text { change in baseline TBL }\end{array}$ & None & $\begin{array}{l}\text { Repeat ALT, AST, ALP, TBL, INR, albumin } \\
\text { and obtain HBV DNA }{ }^{\mathrm{d}} \text { in } 2-3 \mathrm{~d} \text {. If ab- } \\
\text { normality persists, consider interrupting } \\
\text { study drug and initiate close monitoring } \\
\text { until levels return toward nadir values. } \\
\text { Evaluate for etiology of ALT elevation } \\
\text { (Table 6). Study drug can be restarted } \\
\text { only if a self-limited non-drug etiology is } \\
\text { identified }\end{array}$ \\
\hline $\begin{array}{l}\text { Normal baseline: } \\
\text { ALT } \geq 3 \times \text { ULN } \\
\text { Elevated baseline }^{\mathrm{b}} \text { : } \\
\text { ALT } \geq 2 \times \text { baseline (or } \geq 2 \times \\
\text { new nadir }{ }^{\mathrm{C}} \text { ) or } \geq 500 \mathrm{U} / \mathrm{L} \\
\text { (whichever occurs first) }\end{array}$ & $\begin{array}{l}\text { Normal } \\
\text { Patients with Gilbert's syndrome: No } \\
\text { change in baseline TBL }\end{array}$ & $\begin{array}{l}\text { Severe fatigue, nausea, } \\
\text { vomiting, right upper } \\
\text { quadrant pain }\end{array}$ & $\begin{array}{l}\text { Immediately interrupt study drug }{ }^{f} \text {. Repeat } \\
\text { ALT, AST, ALP, TBL, INR, albumin and } \\
\text { obtain HBV DNA }{ }^{\text {d }} \text { in } 2-3 \text { d. Initiate close } \\
\text { monitoring }{ }^{\text {e }} \text { until levels return toward } \\
\text { nadir values. Evaluate for etiology of ALT } \\
\text { elevation (Table 6). Study drug can be } \\
\text { restarted only if a self-limited non-drug } \\
\text { etiology is identified }\end{array}$ \\
\hline $\begin{array}{l}\text { Normal baseline: } \\
\text { ALT } \geq 3 \text { ULN } \\
\text { Elevated baseline }^{b} \text { : } \\
\text { ALT } \geq 3 \times \text { baseline (or } \geq 3 \times^{\text {new nadir }} \text { ) or } \geq 300 \mathrm{U} / \mathrm{L} \\
\text { (whichever occurs first) }\end{array}$ & $\begin{array}{l}\text { TBL } \geq 2 \times \text { ULN } \\
\text { Patients with Gilbert's syndrome: } \\
\text { Doubling of direct bilirubin }\end{array}$ & None & $\begin{array}{l}\text { Immediately interrupt study drug }{ }^{f} \text {. Repeat } \\
\text { ALT, AST, ALP, TBL, INR, albumin and } \\
\text { obtain HBV DNA }{ }^{d} \text { in } 2-3 \text { d } \\
\text { Initiate close monitoring }{ }^{\mathrm{e}} \text { until levels } \\
\text { return toward nadir values. Evaluate for } \\
\text { etiology of ALT elevation (Table 6). Study } \\
\text { drug can be restarted only if a self-lim- } \\
\text { ited non-drug etiology is identified }\end{array}$ \\
\hline
\end{tabular}

Notes: Modified from reference. ${ }^{45}$

Abbreviations: Alb, albumin; ALP, alkaline phosphatase; ALT, alanine aminotransferase; AST, aspartate aminotransferase; TBL, total bilirubin; ULN, upper limit of normal.

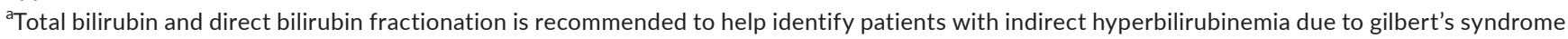
and hemolysis versus liver injury.

${ }^{b}$ Elevated baseline is defined as ALT $\geq 1.5 \times$ ULN.

'In patients with a stable decrease in ALT during treatment (>50\% of baseline value), a new baseline, corresponding to the ALT nadir, should be established as reference for subsequent determination of a DILI signal.

${ }^{\mathrm{d}}$ Additional recommended HBV-related tests: quantitative hepatitis B surface antigen (HBsAg quant), quantitative hepatitis B e antigen (HBeAg quant), quantitative hepatitis B surface antibody (anti-HBs quant)

${ }^{e}$ Frequency of monitoring may need to be adjusted based on clinical scenario and severity of injury.

${ }^{f}$ Drug interruption and discontinuation decisions should involve assessment for other causes of abnormal hepatic biochemical tests including HBV reactivation as well as the half-life and dosing interval of the investigational agent (see Table 6). In some instances, NRTIs may be continued in patients receiving these agents in combination with an investigational drug.

more likely a desired therapeutic effect, due to an increase in viral replication, due to a coincidental liver injury, or a manifestation of DILI by the investigational agent. Per Tables 4 and 5, we generally recommend repeating a liver biochemistry profile in any patient with an isolated serum ALT $>3 \times$ ULN or $>3 \times$ post-baseline nadir within 3-5 days to rule out a laboratory error, re-evaluate concomitant liver function parameters and serum HBV DNA level to assess whether the rising ALT is associated with rising or falling HBV viremia. ${ }^{54}$ Importantly, any patient experiencing symptoms suggestive of hepatitis or with concomitant significant deterioration in total bilirubin, INR or albumin levels may require immediate drug discontinuation.

While repeating laboratory values to confirm a persistent abnormality, it is advisable that the investigator brings the patient in for an unscheduled study visit, to perform a physical examination and determine whether the patient's medical history has changed (ie intercurrent infections and new medications). Confirmation of patient adherence to the study drug regimen is important since missed doses could lead to renewed burst of viral replication and concomitant serum ALT flare. Obtaining blood samples 
TAB LE 6 Recommended evaluation of Hepatitis B patients with unexplained serum liver biochemistry abnormalities in clinical trials.

\begin{tabular}{|c|c|c|}
\hline Competing cause & Recommended evaluation ${ }^{a}$ & Interpretation \\
\hline $\begin{array}{l}\text { Liver directed medical history and } \\
\text { physical exam }\end{array}$ & $\begin{array}{l}\text { Recent travel/ exposures } \\
\text { Alcohol consumption } \\
\text { Exercise \& activity } \\
\text { Concomitant medications \& HDS product consumption }\end{array}$ & $\begin{array}{l}\text { Consider HAV, HCV, HDV, HEV } \\
\text { If excessive or AST/ ALT > } 2 \text { consider lab } \\
\text { testing }^{\text {a }} \\
\text { Possible rhabdomyolysis } \\
\text { Drug hepatotoxicity and acetaminophen } \\
\text { hepatotoxicity }\end{array}$ \\
\hline Acute HAV & Anti-HAV (IgM) & Acute HAV infection \\
\hline Acute HCV & $\begin{array}{l}\text { Anti- HCV } \\
\text { HCV RNA (PCR) }\end{array}$ & $\begin{array}{l}\text { Parenteral exposure/ risk factor } \\
\text { Acute HCV may be anti-HCV (-) but } \\
\text { HCV RNA (+) }\end{array}$ \\
\hline Muscle injury & $\begin{array}{l}\text { Excessive muscle use history } \\
\text { Serum CPK, aldolase }\end{array}$ & $\begin{array}{l}\text { Compare to baseline values, AST fre- } \\
\text { quently elevated as well }\end{array}$ \\
\hline \multicolumn{3}{|l|}{ 2nd line testing ${ }^{b}$} \\
\hline Autoimmune hepatitis & $\begin{array}{l}\text { ANA, SmAb } \\
\text { Quantitative IgG, IgM, IgA }\end{array}$ & $\begin{array}{l}\text { Compare to available baseline } \\
\text { Liver biopsy needed to confirm a diag- } \\
\text { nosis of AlH }\end{array}$ \\
\hline Hepatic ischemia & $\begin{array}{l}\text { Review of blood pressure/ pulse } \\
\text { Electrocardiogram }\end{array}$ & $\begin{array}{l}\text { Echocardiogram or cardiology consult } \\
\text { may be indicated }\end{array}$ \\
\hline Other hepatotoxins & Urine toxicology screen & $\begin{array}{l}\text { Cocaine, opiates and other illicit sub- } \\
\text { stances may cause liver damage }\end{array}$ \\
\hline Cholestasis of sepsis & Review of all medical records & Clinical diagnosis of exclusion \\
\hline
\end{tabular}

${ }^{a}$ Extent and type of work-up may vary by patient location and flare severity; all patients with jaundice should undergo liver imaging.

${ }^{\mathrm{b}}$ This testing should be undertaken in patients without an identified cause of acute liver injury after initial evaluation.

${ }^{\mathrm{C}} \mathrm{A}$ reference lab with a rapid turnaround time that can confirm anti-HEV IgM positive samples with nested PCR should be considered.

to identify unusual causes of liver injury, study drug blood levels and HBV efficacy markers may also prove worthwhile. In addition to increasing the frequency of liver safety biomarker testing to at least twice-weekly until the liver biochemistries improve, the investigator should obtain serial quantitative HBV DNA levels to confirm whether the patient is exhibiting an efficacy response or viral breakthrough. Evaluations for alternative causes of liver injury should be undertaken in a stepwise manner as guided by the clinical circumstances (Table 6). When ALT elevations cannot be presumptively ascribed to a marked efficacy response or HBV viral resistance, further assessments may include serum CPK levels, non-HBV viral hepatitis markers and alcohol biomarkers. ${ }^{3}$ In addition, a repeat liver imaging study should be obtained in any patient with suspected HCC, gallstones or pancreatitis. If the above testing is unrevealing and signs of liver injury persist, it is advisable to order additional serological testing for other mimickers of DILI such as acute HEV infection (ie anti-HEV IgM, anti-HEV IgG and HEV RNA), autoimmune hepatitis (ANA, Smith antibody and quantitative immunoglobulins), and cytomegalovirus (CMV) or EpsteinBarr virus (EBV) infection (CMV DNA and EBV DNA).

\section{7 | INTERPRETATION OF LIVER SAFETY DATA IN CLINICAL TRIALS}

A clinical trial protocol should include a prespecified algorithm on how to adjudicate liver safety signals in studies of investigational agents for chronic HBV. In addition to frequency tables assessing the incidence and severity of liver safety biomarker laboratory data in treatment arms, treatment dose or duration effect, patient 
demographics, HBV parameters, liver disease parameters and other clinical factors should be considered. The timing of liver safety signal data in relationship to results from investigational assays assessing drug efficacy should also be considered.

For any patient who experiences an episode of liver injury during or after treatment with the study drug that is marked by an ALT > $5 \times$ ULN or $>3 \times$ baseline, ALK $>2 \times$ ULN, elevation in total bilirubin or if the study drug has been held or discontinued because of liver abnormalities, the local investigator should create a clinical narrative that includes the pertinent medical history and findings of additional diagnostic testing that were done (Table 6). If a liver biopsy was performed, available slides should be obtained and reviewed by an independent expert liver pathologist as part of the causality assessment review. In addition, the investigator will need to make a personal assessment of causality and relatedness to the study drug reporting these judgements in the patient's case record. If the episode meets regulatory criteria for a serious adverse event (SAE), the investigator must promptly notify the study sponsor and expeditiously complete a SAE report (usually with a CIOMS form) for sponsor transmission to regulatory authorities and ethics committees. ${ }^{55}$ If a potential pattern of liver safety signals emerges in a clinical trial of an investigational agent, it is advisable that the sponsor convene an independent adjudication committee to review all available liver safety data and make recommendations regarding study discontinuation vs continuation with any needed changes in the study protocol. ${ }^{21}$

\section{8 | COLLECTION OF PRETREATMENT DNA AND ON TREATMENT BIOBANKED SAMPLES}

Liver safety issues are a leading reason for drugs to fail in clinical development. ${ }^{56}$ With a typically low incidence in drug-exposed patients, genetic variation in host receptors, metabolic pathways and/or immune response may be involved in idiosyncratic DILI pathogenesis. ${ }^{57}$ Studies exploring the mechanism and risk factors for drugs that did not gain regulatory approval due to DILI have identified high-risk patients using genomic and immunological methods. ${ }^{58}$ Therefore, sponsors are encouraged to collect a predosing DNA sample in all clinical trial participants in the event that untoward adverse events such as DILI are noted during the drug development programme. In addition, blood samples for efficacy and safety markers should be obtained at baseline and at key study visits during and at the end of dosing and follow-up so that future studies of DILI risk vs drug benefit can be undertaken.

\section{9 | CONCLUSIONS}

Various laboratory, clinical and histological criteria should be considered in the design of future phase 1 and $2 / 3$ studies of investigational regimens for chronic HBV (Table 3). To adjudicate serum ALT flares encountered in these drug development programmes, a predefined protocol that specifies the testing of liver safety biomarkers prior to and during treatment should be established and followed (Tables 4 and 5). Furthermore, investigation of individual cases of liver biomarker safety signals using a comprehensive and methodical approach is advisable. When a potential pattern of DILI events is identified in trials of new anti-HBV agents, an expert adjudication panel is recommended to help assess the overall preclinical, clinical and pharmacological liver safety data. Finally, molecular diagnostic assays that can reliably differentiate an enhanced host immune response to HBV antigens vs drug hepatotoxicity are in development and will hopefully improve our ability to develop safe and effective medications that increase the rate of $\mathrm{HBsAg}$ loss in the millions of patients with chronic HBV worldwide.

\section{DISCLOSURES}

Robert Fontana: receives research funding from BMS, Gilead and Abbvie and has provided consulting for Alynam/ Sanofi. Mark Avigan: reports nothing to disclose. Harry Janssen: has received grants from AbbVie, Bristol Myers Squibb, Gilead Sciences, Janssen, Medimmune, Merck and Roche, and is a consultant for AbbVie, Benitec, Bristol Myers Squibb, Gilead Sciences, Janssen, Medimmune, Merck, Roche, Arbutus, Vir Biotechnology Inc Arie Regev: is a full-time employee of Eli Lilly and owns stocks of Eli Lilly. Poonam Mishra: reports nothing to disclose. Anuj Gaggar: is an employee of Gilead Biosciences. Nathaniel Brown: consultancies with two small companies, one HBVfocused and one HCV-focused. Cynthia Wat: is an employee of Roche and has stockholdings in Roche. Patricia Mendez: is an employee of Mallinckrodt Pharmaceuticals. Ryan Anderson: reports nothing to disclose. Bruce Given: reports that he is an employee and shareholder of Arrowhead Pharmaceuticals, Inc Veronica Miller: reports support from Abbott Molecular, Aicuris, Altimmune, Arbutus Biopharma, Arrowhead Pharmaceuticals, Assembly Biosciences, Astra Zeneca, ContraVir, DDL Diagnostics, Gilead Sciences, GlaxoSmithKline, Hepatitis B Foundation, Janssen, MEDIAN Technologies, Novartis, PPD, Quest Diagnostics, Roche Molecular Systems and Springbank Pharma. Maria Beumont: is an employee of Johnson and Johnson.

\section{AUTHOR CONTRIBUTIONS}

All the authors contributed to the manuscript design, drafting, figures and final review.

\section{DISCLAIMER}

The views expressed are those of the authors and do not necessarily represent the position of, nor imply endorsement from, the US Food and Drug Administration or the US Government.

\section{ORCID}

Ryan T. Anderson (iD https://orcid.org/0000-0003-3175-545X

Veronica Miller (iD https://orcid.org/0000-0002-6543-3224 


\section{REFERENCES}

1. Anderson RT, Lim SG, Mishra P, et al. Challenges, considerations, and principles to guide trials of combination therapies for chronic hepatitis B virus. Gastroenterology. 2019;156(3):529-533.e524.

2. Lok AS, Zoulim F, Dusheiko G, Ghany MG. Hepatitis B cure: From discovery to regulatory approval. J Hepatol. 2017;67(4):847-861.

3. Terrault NA, Lok ASF, McMahon BJ, et al. Update on prevention, diagnosis, and treatment of chronic hepatitis B: AASLD 2018 hepatitis B guidance. Hepatology (Baltimore, MD). 2018;67(4):1560-1599.

4. Li WC, Wang MR, Kong LB, Ren WG, Zhang YG, Nan YM. Peginterferon alpha-based therapy for chronic hepatitis $B$ focusing on $\mathrm{HBsAg}$ clearance or seroconversion: a meta-analysis of controlled clinical trials. BMC Infect Dis. 2011;11:165.

5. Levrero M, Subic M, Villeret F, Zoulim F. Perspectives and limitations for nucleo(t)side analogs in future HBV therapies. Curr Opin Virol. 2018;30:80-89.

6. Perrillo RP. Acute flares in chronic hepatitis B: the natural and unnatural history of an immunologically mediated liver disease. Gastroenterology. 2001;120(4):1009-1022.

7. Lesmana CR, Gani RA, Hasan I, et al. Significant hepatic histopathology in chronic hepatitis B patients with serum ALT less than twice ULN and high HBV-DNA levels in Indonesia. J Dig Dis. 2011;12(6):476-480.

8. Cho HJ, Kim SS, Ahn SJ, et al. Serum markers for predicting significant necroinflammatory activity in patients with chronic hepatitis B. Clin Biochem. 2012;45(18):1564-1567.

9. Liaw YF, Chu CM, Su IJ, Huang MJ, Lin DY, Chang-Chien CS Clinical and histological events preceding hepatitis $\mathrm{B}$ e antigen seroconversion in chronic type B hepatitis. Gastroenterology. 1983;84(2):216-219.

10. Lok AS, McMahon BJ. Chronic hepatitis B: update 2009. Hepatology (Baltimore, MD). 2009;50(3):661-662.

11. Vanwolleghem T, Hou J, van Oord G, et al. Re-evaluation of hepatitis $B$ virus clinical phases by systems biology identifies unappreciated roles for the innate immune response and B cells. Hepatology (Baltimore, MD). 2015;62(1):87-100.

12. Liaw YF, Brunetto MR, Hadziyannis S. The natural history of chronic HBV infection and geographical differences. Antivir Ther 2010;15(Suppl 3):25-33.

13. Chang ML, Liaw YF. Hepatitis B flares in chronic hepatitis B: pathogenesis, natural course, and management. J Hepatol. 2014;61(6):1407-1417.

14. Brahmania $M$, Lombardero $M$, Hansen $B E$, et al. Association Between Severe Serum Alanine Aminotransferase Flares and Hepatitis B e Antigen Seroconversion and HBV DNA Decrease in Untreated Patients With Chronic HBV Infection. Clin Gastroenterol Hepatol. 2019;17:2541-2551.e2

15. Hadziyannis SJ, Vassilopoulos D. Hepatitis B e antigen-negative chronic hepatitis B. Hepatology. 2001;34:617-624.

16. Hsu YS, Chien RN, Yeh CT, et al. Long-term outcome after spontaneous $\mathrm{HBeAg}$ seroconversion in patients with chronic hepatitis $\mathrm{B}$. Hepatology. 2002;35(6):1522-1527.

17. Höner zu Siederdissen C, Maasoumy B, Cornberg M. What is new on $\mathrm{HBsAg}$ and other diagnostic markers in HBV infection? Best Pract Res Clin Gastroenterol. 2017;31(3):281-289.

18. Honkoop P, de Man RA, Niesters HG, Zondervan PE, Schalm SW Acute exacerbation of chronic hepatitis $B$ virus infection after withdrawal of lamivudine therapy. Hepatology (Baltimore, MD). 2000;32(3):635-639.

19. Brunetto MR, Oliveri F, Coco B, et al. Outcome of anti-HBe positive chronic hepatitis $\mathrm{B}$ in alpha-interferon treated and untreated patients: a long term cohort study. J Hepatol. 2002;36(2):263-270.

20. Liaw YF, Leung NW, Chang TT, et al. Effects of extended lamivudine therapy in Asian patients with chronic hepatitis B. Asia Hepatitis Lamivudine Study Group. Gastroenterology. 2000;119(1):172-180.
21. Papatheodoridis G, Vlachogiannakos I, Cholongitas E, et al. Discontinuation of oral antivirals in chronic hepatitis B: A systematic review. Hepatology. 2016;63:1481-1492.

22. Su TH, Yang HC, Tseng TC, et al. Distinct relapse rates and risk predictors after discontinuing tenofovir and entecavir therapy. J Inf Dis. 2018;217:1193-1201.

23. Siederdissen $\mathrm{CH}$, Hui AJ, Sukeepaisarnjaroen W, et al. Contrasting timing of virological relapse after discontinuation of tenofovir or entecavir in hepaitits B e antigen- negative patients. J Inf Dis. 2018;218:1480-1484

24. FDA. Guidance for Industry: Chronic Hepatitis B Virus Infection: Developing Drugs for Treatment. In: U.S. Department of Health and Human Services, ed. Silver Spring, Maryland: U.S. Food and Drug Administration; 2018.

25. Hadziyannis SJ, Sevastianos V, Rapti I, Vassilopoulos D, Hadziyannis E. Sustained responses and loss of $\mathrm{HBsAg}$ in $\mathrm{HBeAg}$-negative patients with chronic hepatitis B who stop long-term treatment with adefovir. Gastroenterology. 2012;143(3):629-636.e621.

26. Berg T, Simon KG, Mauss S, et al. Long-term response after stopping tenofovir disoproxil fumarate in non-cirrhotic $\mathrm{HBeAg}$-negative patients - FINITE study. J Hepatol. 2017;67(5):918-924.

27. Chen $\mathrm{CH}$, Lu SN, Hung $\mathrm{CH}$, et al. The role of hepatitis $\mathrm{B}$ surface antigen quantification in predicting $\mathrm{HBsAg}$ loss and $\mathrm{HBV}$ relapse after discontinuation of lamivudine treatment. J Hepatol. 2014;61(3):515-522.

28. Jeng WJ, Sheen IS, Chen YC, et al. Off-therapy durability of response to entecavir therapy in hepatitis $B$ e antigen-negative chronic hepatitis B patients. Hepatology. 2013;58(6):1888-1896.

29. Jeng WJ, Chen YC, Chien RN, et al. Incidence and predictors of Hepatitis B surface antigen seroclearance after cessation of nucleos(t)ide analogue Therapy in Hepatitis $B$ e antigen- negative Chronic Hepatitis B. Hepatology. 2018;68:425-434.

30. Lampertico P, Berg T. Less can be more: A Finite treatment approach for $\mathrm{HBeAg}$-negative chronic hepatitis B. Hepatology. 2018;68:397-3999.

31. Bjornsson ES, Hoofnagle JH. Categorization of drugs implicated in causing liver injury: Critical assessment based on published case reports. Hepatology. 2016;63(2):590-603

32. Navarro VJ, Khan I, Bjornsson E, Seeff LB, Serrano J, Hoofnagle $\mathrm{JH}$. Liver injury from herbal and dietary supplements. Hepatology (Baltimore, MD). 2017;65(1):363-373.

33. Fontana RJ, Seeff LB, Andrade RJ, et al. Standardization of nomenclature and causality assessment in drug-induced liver injury: summary of a clinical research workshop. Hepatology. 2010;52(2):730-742.

34. Mishra P, Chen M. Direct-acting antivirals for chronic hepatitis $\mathrm{C}$ : can drug properties signal potential for liver injury? Gastroenterology. 2017;152(6):1270-1274

35. Agarwal VK, McHutchison JG, Hoofnagle JH. Important elements for the diagnosis of drug-induced liver injury. Clin Gastro Hepatol. 2010;8(5):463-470.

36. Rockey DC, Seeff LB, Rochon J, et al. Causality assessment in drug-induced liver injury using a structured expert opinion process: comparison to the Roussel-Uclaf causality assessment method. Hepatology. 2010;51(6):2117-2126.

37. Fontana RJ, Watkins PB, Bonkovsky HL, et al. Drug-Induced Liver Injury Network (DILIN) prospective study: rationale, design and conduct. Drug Saf. 2009;32(1):55-68.

38. Zimmerman HJ. Hepatotoxicity: the adverse effects of drugs and other chemicals on the liver. 2nd ed. Philadelphia, PA: Lippincott Williams \& Wilkins; 1999.

39. Bjornsson E, Olsson R. Outcome and prognostic markers in severe drug-induced liver disease. Hepatology. 2005;42(2):481-489.

40. FDA/CDER/CBER. Guidance for Industry Drug-Induced Liver Injury: Premarketing Clinical Evaluation. In: U.S. Department of Health and 
Human Services, ed. Silver Spring, Maryland: U.S. Food and Drug Administration; 2009;25

41. Panteghini M, Adeli K, Ceriotti F, Sandberg S, Horvath AR. American liver guidelines and cutoffs for "normal" ALT: a potential for overdiagnosis. Clin Chem. 2017;63(7):1196-1198.

42. Liaw YF, Gane E, Leung N, et al. 2-Year GLOBE trial results: telbivudine Is superior to lamivudine in patients with chronic hepatitis $B$. Gastroenterology. 2009;136(2):486-495.

43. Marcellin P, Heathcote EJ, Buti M, et al. Tenofovir disoproxil fumarate versus adefovir dipivoxil for chronic hepatitis B. N Engl J Med. 2008;359(23):2442-2455.

44. Avigan MI, Bjornsson ES, Pasanen M, et al. Liver safety assessment: required data elements and best practices for data collection and standardization in clinical trials. Drug Saf. 2014;37(Suppl 1):S19-31.

45. Afdhal N, Zeuzem S, Kwo P, et al. Ledipasvir and sofosbuvir for untreated HCV genotype 1 infection. N Engl J Med. 2014;370(20):1889-1898.

46. Singh S, Muir AJ, Dieterich DT, Falck-ytter YT. Amercian Gastroenterogical Association Institute Technical Review on the role of liver elastography in chronic liver Diseases. Gastroenterology. 2017;152:1544-1577.

47. Sterling RK, King WC, Wahed AS, et al. Evaluating noninasive markers to Identify advanced fibrosis by liver biopsy in HBV/ HIV co-infected adults. Hepatology. 2019. Accepted June 20, 2019. https:// doi.org/10.1002/hep.30825

48. Miailhes $\mathrm{P}$, Pradat $\mathrm{P}, \mathrm{Chevallier} \mathrm{M}$, et al. Proficiency of transient elastography compared to liver biopsy for the assessment of fibrosis in HIV/ HBV co-infected patients. J Viral Hepatitis. 2011;18:61-69.

49. Abbas Z, Jafri W, Raza S. Hepatitis D: Scenario in the Asia-Pacific region. World J Gastroenterol. 2010;16(5):554-562.

50. Koh C, Canini L, Dahari H, et al. Oral prenylation inhibition with lonafarnib in chronic hepatitis $\mathrm{D}$ infection: a proof-of-concept randomised, double-blind, placebo-controlled phase 2A trial. Lancet Infect Dis. 2015;15(10):1167-1174.

51. Puoti $M$, Airoldi $M$, Bruno R, et al. Hepatitis $B$ virus co-infection in human immunodeficiency virus-infected subjects. AIDS Rev. 2002;4(1):27-35.

52. Sulkowski MS, Thomas DL, Chaisson RE, Moore RD. Hepatotoxicity associated with antiretroviral therapy in adults infected with human immunodeficiency virus and the role of hepatitis $C$ or $B$ virus infection. JAMA. 2000;283(1):74-80.

53. Tassopoulos NC, Volpes R, Pastore G, et al. Efficacy of lamivudine in patients with hepatitis $B$ e antigen-negative/hepatitis $B$ virus DNA-positive (precore mutant) chronic hepatitis B. Lamivudine Precore Mutant Study Group. Hepatology (Baltimore, MD). 1999;29(3):889-896.

54. Chalasani N, Regev A. Drug-induced liver injury in patients with preexisting chronic liver disease in drug development: how to identify and manage? Gastroenterology. 2016;151(6):1046-1051.

55. FDA. Guidance for Industry and Investigators: Safety Reporting Requirements for INDs and BA/BE Studies. In: U.S. Department of Health and Human Services, ed. Silver Spring, Maryland: U.S. Food and Drug Administration; 2012.

56. Wysowski DK, Swartz L. Adverse drug event surveillance and drug withdrawals in the United States, 1969-2002: the importance of reporting suspected reactions. Arch Intern Med. 2005;165(12):1363-1369.

57. Fontana RJ. Pathogenesis of idiosyncratic drug-induced liver injury and clinical perspectives. Gastroenterology. 2014;146(4):914-928.

58. Singer JB, Lewitzky S, Leroy E, et al. A genome-wide study identifies HLA alleles associated with lumiracoxib-related liver injury. Nat Genet. 2010;42(8):711-714.

\section{SUPPORTING INFORMATION}

Additional supporting information may be found online in the Supporting Information section.

How to cite this article: Fontana RJ, Avigan MI, Janssen HLA, et al. Liver safety assessment in clinical trials of new agents for chronic hepatitis B. J Viral Hepat. 2020;27:96-109. https://doi. org/10.1111/jvh.13223 